\title{
A new species of casque-headed tree frog, genus Aparasphenodon Miranda-Ribeiro (Amphibia: Anura: Hylidae), from the Atlantic Rainforest of southern Bahia, Brazil
}

\author{
BRUNO V. S. PIMENTA ${ }^{1}$, MARCELO F. NAPOLI ${ }^{2,3,5}$ \& CÉLIO F. B. HADDAD ${ }^{4}$ \\ ${ }^{1}$ BBM Consultoria Ambiental Ltda., Av. Prudente de Morais, 621/807, Cidade Jardim, 30380-000, Belo Horizonte, Minas Gerais, \\ Brazil. E-mail: bvergueiropimenta@gmail.com \\ ${ }^{2}$ Museu de Zoologia, Departamento de Zoologia, Instituto de Biologia, Universidade Federal da Bahia, Campus Universitário, Rua \\ Barão de Jeremoabo, Ondina, 40170-115 Salvador, Bahia, Brazil.E-mail: napoli@ufba.br \\ ${ }^{3}$ Associate Researcher, Departamento de Vertebrados, Museu Nacional/Universidade Federal do Rio de Janeiro, Quinta da Boa Vista, \\ São Cristóvão, 20940-040 Rio de Janeiro, Rio de Janeiro, Brazil. \\ ${ }^{4}$ Departamento de Zoologia, Instituto de Biociências, Universidade Estadual Paulista (UNESP), Caixa Postal 199, $13506-900$ Rio \\ Claro, São Paulo, Brazil. E-mail: haddad1000@gmail.com \\ ${ }^{5}$ Corresponding author. E-mail: napoli@ufba.br
}

\begin{abstract}
A new species of Aparasphenodon is described from patches of arboreal restinga within the Atlantic Forest Biome, in a region known as Baixo Sul in southern Bahia, northeastern Brazil. Aparasphenodon arapapa sp. nov. is promptly diagnosed from other Aparasphenodon mainly by having small size (male snout-vent length 57.4-58.1 mm), loreal region flattened and wide, and canthus rostralis rounded and poorly elevated. The wide and flattened snout resembles that found in Triprion and Diaglena, and possibly is a parallelism (homoplasy) related to the phragmotic behavior of casque-headed tree frogs to their microhabitat usage. The decision to allocate the new species in the genus Aparasphenodon is discussed in detail, as the single morphological synapomorphy of the genus, the presence of a prenasal bone, is insufficient to morphologically relate the new species to Aparasphenodon, Triprion, or Diaglena.
\end{abstract}

Key words: Aparasphenodon arapapa sp. nov., Casque-headed tree frog, Hylinae, taxonomy

\section{Resumo}

Uma nova espécie de Aparasphenodon é descrita, proveniente de fragmentos de restinga situados no Bioma da Floresta Atlântica, em uma região conhecida como Baixo Sul no sul da Bahia, nordeste do Brasil. Aparasphenodon arapapa sp. nov. é prontamente diagnosticada de outros Aparasphenodon principalmente por apresentar tamanho pequeno (comprimento rostro-cloacal em machos 57,4-58,1 mm), região loreal achatada e larga e canto rostral levemente arredondado e pouco elevado. O focinho largo e achatado se assemelha aos de Triprion e Diaglena e possivelmente é um paralelismo (homoplasia) relacionado ao comportamento de fragmose praticado por pererecas-de-capacete no uso de seus micro-hábitats. A decisão de alocar a nova espécie no gênero Aparasphenodon é discutida em detalhe, já que a única sinapomorfia morfológica de Aparasphenodon, a presença de um osso prenasal, é insuficiente para relacionar morfologicamente a nova espécie a Aparasphenodon, Triprion ou Diaglena.

\section{Introduction}

The Neotropical genus Aparasphenodon Miranda-Ribeiro, 1920 is currently composed by three species distributed from northern South America to southern Brazil: A. brunoi Miranda-Ribeiro, 1920, A. bokermanni 
Pombal, 1993, and A. venezolanus (Mertens, 1950). Species ranges are usually geographically restricted, except for A. brunoi, known from the southern region of the State of Bahia, northeastern Brazil, to the State of São Paulo, southeastern Brazil (Argôlo, 2000; Frost, 2008). Aparasphenodon is placed among the casqueheaded hylids, mainly characterized by their co-ossified skulls and phragmotic behavior (using the head to plug burrows) related to their microhabitat usage. Trueb (1970) reviewed the casque-headed tree frogs and defined Aparasphenodon as having skull longer than broad, snout narrow and acuminate in dorsal view, distinct canthal ridges, prenasal bones, and single, median, subgular vocal sac, among other traits. Faivovich et al. (2005) placed Aparasphenodon among the Lophiohylini Miranda-Ribeiro, 1926 on the basis of molecular evidences, mentioning that a possible morphological synapomorphy for this genus is the presence of the prenasal bones (known homoplastic instance in Triprion Cope, 1866, genus placed among the Hylini Rafinesque, 1815, sister-taxon of Lophiohylini).

Surveys of amphibians in patches of arboreal restinga in a region known as Baixo Sul in eastern Bahia, northeastern Brazil, resulted in the collection of small specimens of Aparasphenodon. Their comparison with specimens of the known species and with literature data revealed that they belong to a new species, described herein.

\section{Material and methods}

Museum abbreviations of specimens used in the descriptions or examined for comparisons followed Leviton et al. (1985) with the corrections and additions by Frost (2008), except for Coleção Herpetológica do Departamento de Zoologia, Universidade Federal de Minas Gerais (DZ-UFMG); Museu de Zoologia da Universidade Federal da Bahia (UFBA); and Museu de História Natural "Professor Adão José Cardoso", Universidade Estadual de Campinas (ZUEC).

Measurements of specimens follow Napoli (2005) and are in millimeters: SVL (snout-vent length), HL (head length), HW (head width), ED (eye diameter), UEW (upper eyelid width), IOD (interorbital distance), IND (internarial distance), TD (tympanum diameter), END (eye to nostril distance), NSD (nostril to tip of snout distance), 3FD (third finger disk diameter), THL (thigh length), TL (tibia length), FL (foot length), and 4TD (fourth toe disk diameter). Measurements were taken with an ocular micrometer in an Olympus SZ40 stereomicroscope, except for SVL, HL, HW, THL, TL, and FL, which were measured with a vernier caliper. Drawings of the holotype were made using a Leica-Wild MZ6 stereomicroscope with a drawing tube. Webbing formula notation followed Savage and Heyer (1967) as modified by Myers and Duellman (1982).

$\mathrm{X}$-ray images of the holotype were used to corroborate generic assignment made through external morphology evidences. Radiographs were obtained with a FAXITRON X-ray MX-20 Radiograph System and software Specimen DR version 2.0.1. External morphologic features of the new species were compared with those from A. venezolanus only by means of published data (Paolillo \& Cerda, 1981). Comparisons with $A$. bokermanni were made by examination of the only specimens available in herpetological collections, the holotype and one specimen from a neighboring municipality. Comparisons with the currently known species of Aparasphenodon were favored mainly by their very distinctive morphologies relative to the new species described herein.

\section{Taxonomic account}

Aparasphenodon arapapa sp. nov.

Bahia's broad-snout casque-headed tree frog

Figures 1-2

Holotype. UFBA 3948, adult male, collected at Área de Proteção Ambiental (APA) Pratigi (1344' S, 3901' 
W, 27 m above sea level), Municipality of Ituberá, State of Bahia, Brazil, on 25 November 2003, by R.A. Machado.

Paratype. CFBH 3700, adult male, collected at Fazenda Subaúma $\left(13^{\circ} 31^{\prime}\right.$ S, 39 $03^{\prime}$ W, $20 \mathrm{~m}$ above sea level), Municipality of Cairu, State of Bahia, Brazil, on 02 September 2000, by B.V.S. Pimenta and R.V. Lopes.

Diagnosis. Species characterized by the following combination of traits: (1) size small (male SVL 57.4-58.1 mm); (2) head longer than wide, its length 2.6 times smaller than snout-vent length; (3) canthus rostralis curved, rounded, poorly elevated, not outlining straight sharp ridges; (4) loreal region flattened, slightly concave, its greater diameter wider than the larger distance between the canthi rostrales; (5) maxilla expanded laterally; (6) eye large (ED/SVL 0.1), directed forward; (7) tympanum medium-sized, nearly circular, its width 1.9-2.4 times smaller than eye diameter; (8) supratympanic fold developed, partially covering the tympanum; (9) nostrils superolateral; (10) internarial region furrowed, laterally and anteriorly delimited by two bony crests; (11) skin of the dorsal surfaces of the skull poorly co-ossified with underlying bone; (12) fingers lacking webbing; (13) legs short, sum of thigh and tibia lengths $78-82 \%$ of snout-vent length; (14) toes poorly webbed.

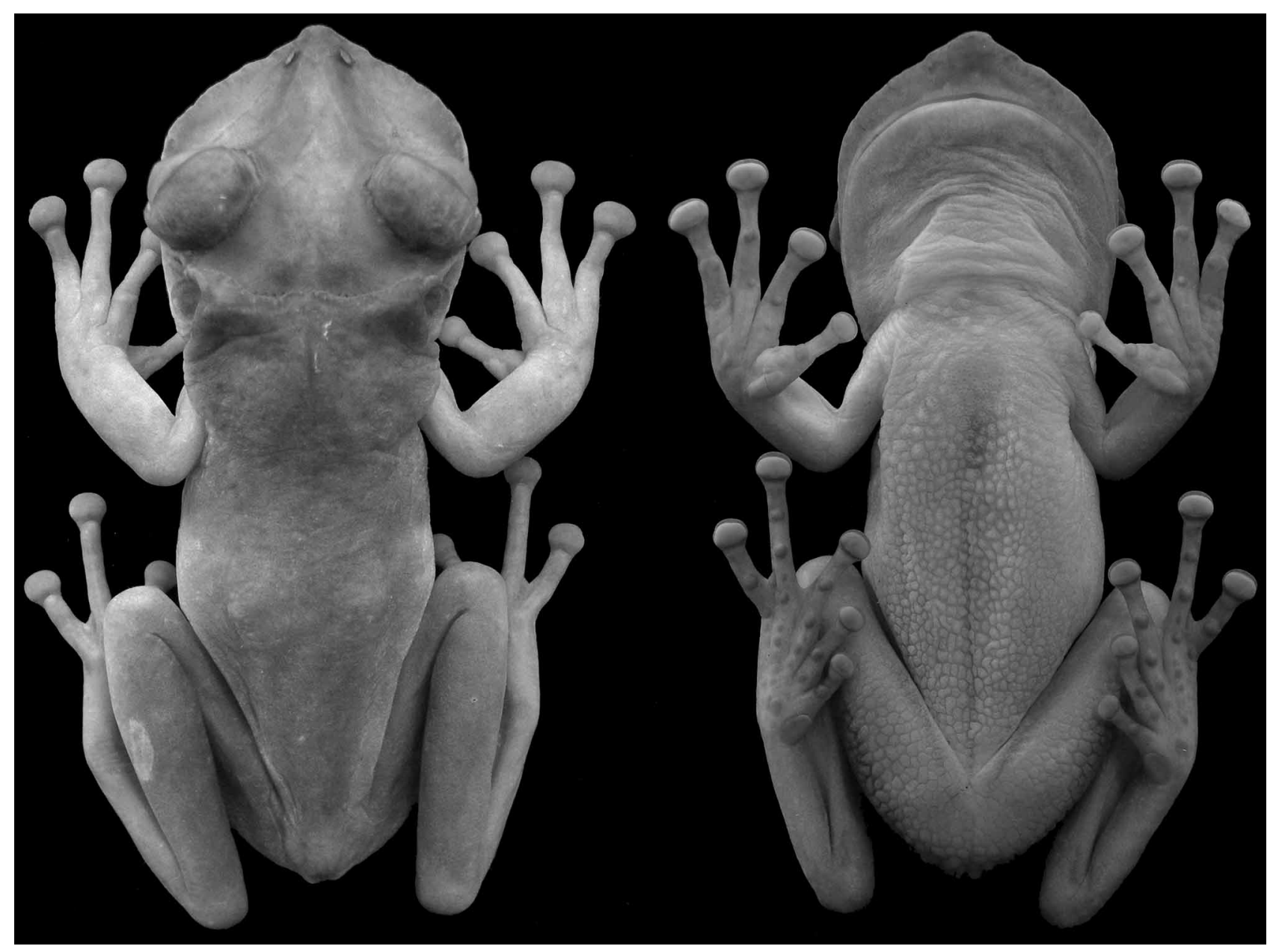

FIGURE 1. Aparasphenodon arapapa sp. nov., holotype, UFBA 3948, adult male, $58.1 \mathrm{~mm}$ SVL. Left, dorsal view; right, ventral view.

Aparasphenodon arapapa presents the loreal region wide and shallow, while all congeneric species have narrow, oblique, and deep loreal regions. The rounded, poorly elevated canthus rostralis, not outlining straight sharp ridges distinguishes A. arapapa from congeneric species, in which it is elevated and ridged. Aparasphenodon arapapa shows laterally expanded maxilla and a labial flange touching the lower eyelid 
(both absent in all congeneric species), eyes directed forward (sideward in all congeneric species), dorsal and lateral surfaces immaculate and light brown (A. bokermanni has dorsum dark brown, head blackish brown, and flanks with cream spots; A. venezolanus and A. brunoi have dorsum marbled with irregular dark brown markings, and arms and legs with transversal dark brown stripes or irregular dark brown markings), nostril superolateral (lateral in all congeneric species), and skin of dorsal surfaces of the skull poorly co-ossified with underlying bone (in all congeneric species it is strongly co-ossified). The new species also differs from $A$. venezolanus by the head longer than wide (wider than long in A. venezolanus), fingers lacking webbing (webbing well developed in A. venezolanus, I 3-3 1/3 II 2-3 III 2 2/3-2 1/2 IV), and toes poorly webbed (well webbed in A. venezolanus, I 1 2/3-2 1/2 II 1 1/3-3 III 1 1/2-2 2/3 IV 2/3-1 1/3). Additionally, A. arapapa also differs from $A$. brunoi by the canthus rostralis slightly curved (straight in the latter species). For distinction from other Neotropical casque-headed tree frogs, see Remarks below.



FIGURE 2. Aparasphenodon arapapa sp. nov., UFBA 3948, holotype, adult male. (A) Dorsal and (B) lateral views of head; (C) hand, and (D) foot. Upper and lower horizontal lines equal $3.0 \mathrm{~mm}$. 
Description of holotype. Body small (58.1 mm SVL). Head longer than wide, its length 2.6 times smaller than snout-vent length. Snout rounded in dorsal outline (Figs 1, 2A), acute in profile (Fig. 2B). Canthus rostralis slightly curved, rounded, poorly elevated, not outlining straight sharp ridges. Loreal region flattened, slightly concave, with its larger diameter wider than the larger distance between the canthi rostrales. Eyes large (ED/SVL 0.1), directed forward. Tympanum medium-sized, nearly circular, its width 2.4 times smaller than eye diameter. Supratympanic fold developed, partially covering the tympanum. Nostrils superolateral. Internarial region furrowed, laterally and anteriorly delimited by two bony crests. Skin of the dorsal surfaces of the skull poorly co-ossified with underlying bone. Choanae elliptical, narrow, elongated. Vomerine teeth row in two straightened oblique posteromedial patches between choanae, with their posterior borders directed towards the posterior margins of the choanae and the anterior borders pointed to the midpoint between them. Vocal slits present, lateral; vocal sac single, subgular. Tongue large, covering almost all the mouth floor, cordiform. Forearm robust; arm slender. Palmar subarticular tubercles rounded (Fig. 2C); distal tubercle of fourth finger bifid; palmar supernumerary tubercles present; palmar tubercle weakly developed. Fingers lacking webbing; fingers disks large, nearly elliptical. Legs short; thigh length smaller than tibia length, sum of them $(45.1 \mathrm{~mm})$ much smaller than snout-vent length $(58.1 \mathrm{~mm})$. Tarsus without calcar; plantar tubercles small (Fig. 2D); inner metatarsal tubercle large, elliptical; outer metatarsal tubercle small; plantar subarticular tubercles rounded; plantar supernumerary tubercles distinct; modal webbing formula, I 2-2 3/4 II 2--3+ III $2^{+}$3 3/4 IV 3 1/2-2 V. Dorsal texture smooth. Belly glandular; ventral surfaces of thighs, throat, and arms smooth; chest weakly grained. In preservative, dorsal surfaces and flanks uniform dull light brown, immaculate. Ventral surfaces cream, immaculate. Color in life is unknown.

Measurements of holotype (mm). SVL 58.1, HL 22.1, HW 17.2, ED 5.9, UEW 4.5, END 9.7, IND 2.7, TD 2.4, IOD 5.7, NSD 3.9, THL 22.1, TL 23.0, FL 30.7, 3FD 2.8, 4TD 2.4.

Variation. The paratype CFBH 3700 presents the same color pattern and general morphology described for the holotype. Measurements of the paratype (mm): SVL 57.4, HL 22.4, HW 16.6, ED 5.9, UEW 4.2, END 9.7, IND 3.0, TD 3.0, IOD 6.3, NSD 4.0, THL 23.2, TL 24.3, FL 30.5, 3FD 2.3, 4TD 2.3.

Habitat. The only two localities where Aparasphenodon arapapa was found (Fig. 3) are characterized by fragmented patches of arboreal "restingas" (see below), in which terrestrial bromeliads and palm trees are very abundant. Holotype and paratype were collected from terrestrial bromeliads, and the latter was producing advertisement calls (not recorded). The forest canopy at the Fazenda Subaúma (in which the paratype was obtained) is characterized by the dominance of the "piaçava" palm tree (Attalea funifera), which is exploited for natural fibers, preventing deforestation. A narrow stream with sandy bottom crosses this forest fragment, accompanied to some extent of flooding areas. Other anuran species found in simpatry with A. arapapa at Fazenda Subaúma were Aplastodiscus sibilatus, Frostius pernambucensis, Gastrotheca fissipes, Ischnocnema bilineata, I. paulodutrai, Phyllodytes luteolus, and P. melanomystax. The two localities where the type-series was collected are $25 \mathrm{~km}$ distant from each other.

The "restinga" is a typical coastal formation grown over sandy soils that has been largely exploited by the real estate business in Brazil. Sazima and Cardoso (1980) have already reported on the decline of some populations of A. brunoi from the State of São Paulo due to the destruction of "restingas". In the Baixo Sul region of Bahia, real estate is not considered a serious threat to this formation, but deforestation for cattle (mainly buffalos) and shrimp farming has increased in the last years. Although the exploitation of the natural fibers produced by the "piaçava" palm tree (Attalea funifera) is a harmless activity to the forest, since trees must be preserved to guarantee its production over the years, the low cost of such a raw product may lead farmers to search for more profitable activities.

Remarks. Faivovich et al. (2005) conducted a systematic review of the frog family Hylidae, from which resulted two main casque-headed clades: a South American/West Indian clade (tribe Lophiohylini MirandaRibeiro, 1926) and a Middle American/Holarctic clade (within tribe Hylini). The genus Aparasphenodon (allocated in Lophiohylini) was diagnosed by the presence of a prenasal bone as the unique possible morphological synapomorphy (only A. brunoi was included in the analysis). However, prenasal bones are also observed in other casque-headed hylids, as in the genus Triprion Cope, 1866 (Duellman, 2001). Recently, 
Smith et al. (2007) re-analyzed phylogenetically the casque-headed hylids of Middle America (Anotheca Smith, 1939; Pternohyla Boulenger, 1882; Smilisca Cope, 1865; and Triprion) by both molecular and morphological approaches, and also included an additional phylogenetic analysis for the hylid frogs of Lophiohylini. In Lophiohylini, the prenasal evolved once (in Aparasphenodon, thus homoplastic to prenasal of the Middle American genus Triprion) and gained a dermal sphenethmoid four different times (which in turn is homoplastic within Lophiohylini, and also to the Middle American genera Triprion and Diaglena Cope, 1887). This scenario shows that novel cranial elements (non apomorphic modifications of pre-existing structures), like that present on the skull roof of casque-headed hylids (e.g., dermal sphenethmoid, prenasal, and internasal), have evolved in parallel within these hylids as a whole. Yet, Smith et al. (2007) results pointed out that these novel elements are associated to phragmotic behavior (using the head to plug burrows), which suggests that they may have adaptive functional and ecological significance, which in turn favors the development of such structures by parallelism (homoplasy). In this sense, we understand that the presence of a prenasal bone is insufficient to morphologically allocate the new species to Aparasphenodon, Triprion, or Diaglena.

Two other possible morphological synapomorphies that could aid to diagnose the genus Aparasphenodon from Triprion (and consequently from the re-validated Diaglena) stated by Duellman (2001) is the presence in the latter of a maxilla greatly expanded laterally and parasphenoid odontoids. In the new species, although maxillae were not represented in the X-ray images we have obtained from the holotype (and nor a good picture of the parasphenoid, and thus not considered herein), the co-ossified head clearly shows the articulations between maxillae and nasal bones, which allows to distinguish a large flat maxilla in dorsal view, resembling Triprion's maxillae. The main problem to morphologically define a clear distinction between Aparasphenodon and Triprion by means of Duellman's (2001) phylogenetic hypothesis is that the author did not consider South-American species in his analysis, and thus we do not have extensive information about these character states among the latter. Yet, the expanded maxillae of the new species may be another parallelism (homoplasy) related to the phragmotic behavior of casque-headed tree frogs to their microhabitat usage, as demonstrated by Smith et al. (2007) for other skull roof bones of casque-headed hylids (see above).

Another character that could contribute to allocate the new species in the genus Aparasphenodon is the presence of a single, median, subgular vocal sac, considered a diagnostic character state for Aparasphenodon by Trueb (1970), and a primitive state for hylids by Duellman (2001). Almost all West Indian casque-headed hylids have paired subgular sacs (a derived condition), with exception of Diaglena spatulata (Günther, 1882), that presents the primitive condition (a reversal). However, Cochran (1955) and Lynch \& Varga-Ramírez (2000) reported that A. brunoi and A. venezolanus, respectively, present paired lateral vocal sacs resembling those of Osteocephalus and Phrynohyas (now Trachycephalus; see Faivovich et al., 2005), but Rivero (1961) considered Aparasphenodon to have a subgular vocal sac based on his examination of a male of A. brunoi. This character was not available for the holotype of A. bokermanni, since it is a female, but we analyzed a male from the neighboring Municipality of Cananéia, State of São Paulo (ZUEC 11575), and observed that its vocal sac is not like the paired lateral structures seen in Trachycephalus, but rather a single subgular or, at most, paired subgular (bilobate sensu vocal sac standards of Cei, 1980).

In view of the current non conclusive morphological data on which are apomorphic or homoplastic for each South American/West Indian casque-headed taxa, and also to the unknown degree of intra-specific character variation and/or misleading identification of morphological features by previous authors, we decided to allocate the new species in the genus Aparasphenodon, including in our decision the general morphological aspect and the great geographic hiatus between the ranges of Triprion/Diaglena (Middle America: Yucatan peninsula of Mexico, Guatemala, and Honduras; Frost 2008) and Aparasphenodon (coastal lowlands of Brazil and southwestern Venezuela).

Etymology. "Arapapá" is a Tupi indigenous name for the Boat-billed Heron Cochlearius cochlearius (Ciconiiformes, Ardeidae), a paludicolous nocturnal bird occurring from Mexico south to Argentina. Its wide and flattened beak resembles the snout of the new Aparasphenodon described here. The species name is used as a noun in apposition. 

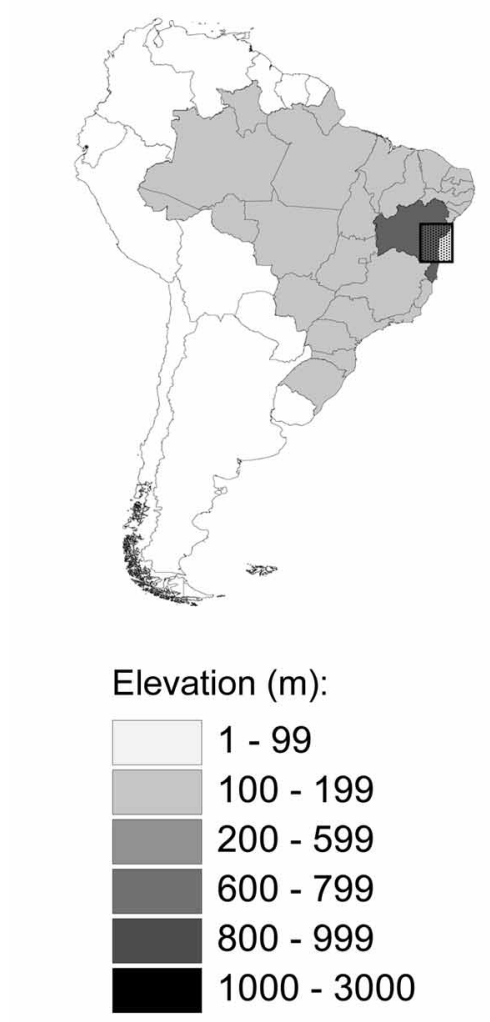

100

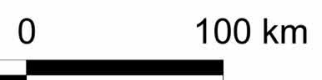

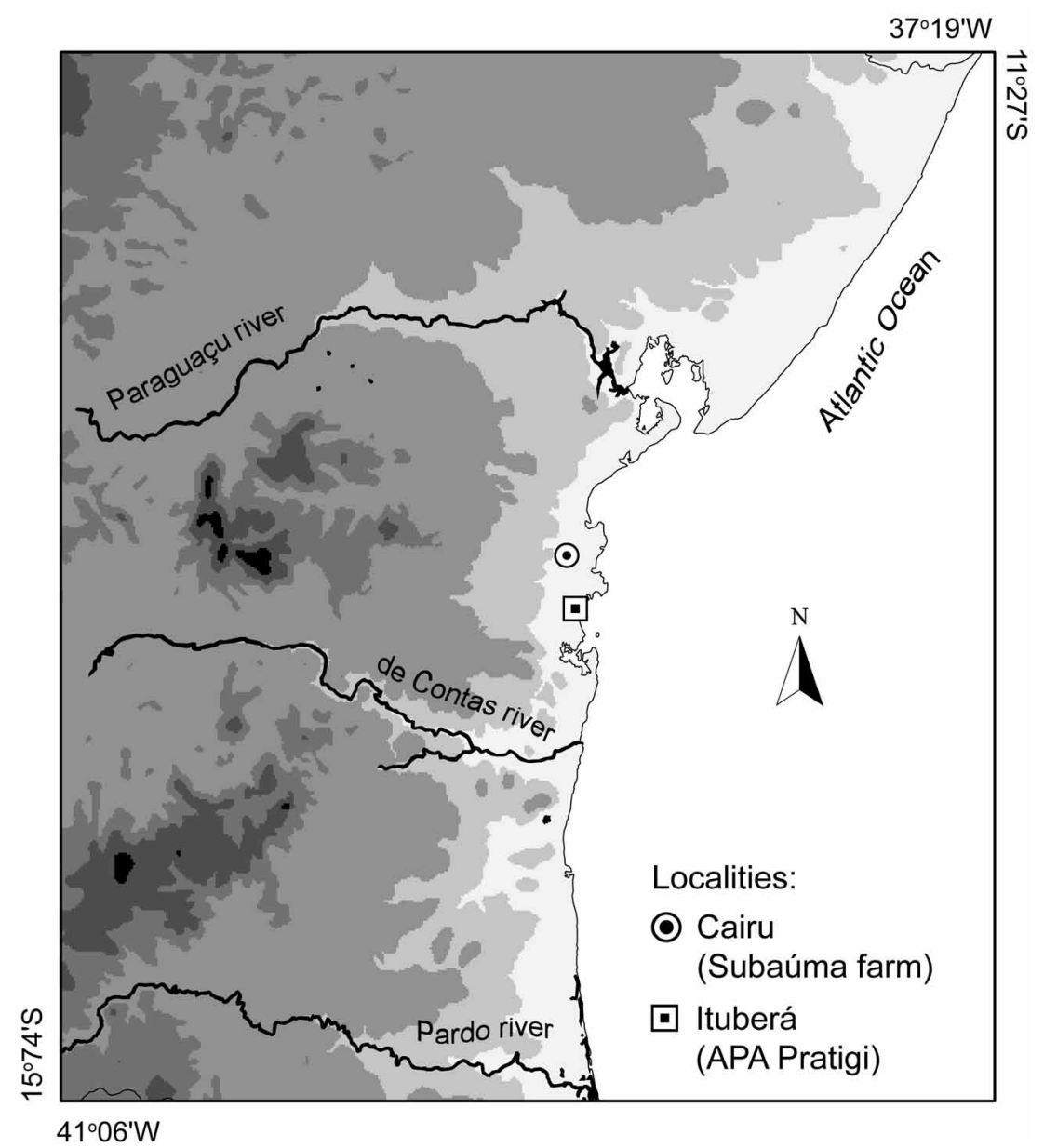

FIGURE 3. Geographic distribution of Aparasphenodon arapapa sp. nov. on topographic map featuring the coastline of the State of Bahia, Brazil.

\section{Acknowledgments}

We are grateful to Tatiana B. Dantas and Milson A. Batista for the efforts to deposit part of the amphibians collection obtained during inventories of APA Pratigi (Municipality of Ituberá, State of Bahia, Brazil), in which the holotype of A. arapapa was captured, in the Museu de Zoologia da Universidade Federal da Bahia. We thank Luciano J. Souza for the line drawings; Rafael O. Abreu for the photograph of the holotype; the Centro de Ecologia e Conservação Animal (ECOA), Universidade Católica do Salvador, State of Bahia, Brazil, for the donation of specimens of A. brunoi to the Museu de Zoologia da Universidade Federal da Bahia (UFBA 7662-7666); R.V. Lopes for help in field work; owners of Fazenda Subaúma for their permission to conduct researches on the anurans occurring in their property. The collection of the paratype was made during the subproject "Abordagens Ecológicas e Instrumentos Econômicos para o Estabelecimento do Corredor do Descobrimento: uma Estratégia para Reverter a Fragmentação Florestal da Mata Atlântica no Sul da Bahia", supported by the Project Conservação e Utilização Sustentável da Diversidade Biológica Brasileira/Ministério do Meio Ambiente (PROBIO/MMA), Center for Applied Biodiversity Science/Conservation International (CABS/CI), World Bank, and coordinated by the Instituto de Estudos Sócio-Ambientais do Sul da Bahia (IESB). CFBH thanks FAPESP and CNPq and MFN the CNPq for financial support. 


\section{References}

Argôlo, A.J.S. (2000) Geographic distribution. Aparasphenodon brunoi. Herpetological Review, 31, 108.

Boulenger, G.A. (1882) Description of a new genus and species of frogs of the family Hylidae. Annals and Magazine of Natural History, 10, 326-328.

Cei, J.M. (1980) Amphibians of Argentina. Monitore Zoologico Italiano (N.S.) Monografia, 2, 1-609.

Cochran, D.M. (1955) Frogs of southeastern Brazil. Bulletin of United States National Museum, 206, 1-423.

Cope, E.D. (1865) Third contribution to the herpetology of tropical America. Proceedings of the Academy of Natural Sciences of Philadelphia, 17, 185-198.

Cope, E.D. (1866) Fourth contribution to the herpetology of tropical America. Proceedings of the Academy of Natural Sciences of Philadelphia, 18, 123-132.

Cope, E.D. (1887) Catalogue of batrachians and reptiles of Central America and Mexico. Bulletin of the United States National Museum, 32, 1-98.

Duellman, W.E. (2001) The Hylid Frogs of Middle America. Society for the Study of Amphibians and Reptiles, Ithaca, New York, 1170 pp.

Faivovich J., Haddad, C.F.B., Garcia, P.C.A., Frost, D.R., Campbell, J.A. \& Wheeler, W.C. (2005) Systematic review of the frog family Hylidae, with special reference to Hylinae: phylogenetic analysis and taxonomic revision. Bulletin of the American Museum of Natural History, 294, 1-240.

Frost, D.R. (2008) Amphibian Species of the World: an Online Reference. Version 5.2 (15 July, 2008). Electronic Database available from http://research.amnh.org/herpetology/amphibia/index.php. New York, American Museum of Natural History (accessed 11 October 2008).

Günther, A.C.L.G. (1882) Notice of a second species of Triprion. Annals and Magazine of Natural History, $10,279$.

Leviton, A.E., Gibbs Jr., R.H., Heal, E. \& Dawson, C.E. (1985) Standards in herpetology and ichthyology. Part 1. Standard symbolic codes for institutional resource collections in herpetology and ichthyology. Copeia, 1985, 802-829.

Lynch, J.D. \& Vargas-Ramirez, M.A. (2000) Lista preliminar de especies de anuros del Departamento del Guainia, Colombia. Revista de la Academia Colombiana de Ciencias Exactas, Físicas y Naturales, 24, 579-589.

Mertens, D. (1950). Ein neuer Laubfrosch aus Venezuela. Senckenbergiana Biologica, 31, 1-2.

Miranda-Ribeiro, A. (1920) Triprion, Diaglena, Corythomantis, etc. uma subsecção de Hylidae, com duas espécies novas. Revista do Museu Paulista, 12, 83-88.

Miranda-Ribeiro, A. (1926) Notas para servirem ao estudo dos Gymnobatrachios (Anura) brasileiros. Arquivos do Museu Nacional, Rio de Janeiro, 27, 1-227.

Myers, C.W. \& Duellman, W.E. (1982) A new species of Hyla from Cerro Colorado, and other tree frog records and geographical notes from Western Panama. American Museum Novitates, 2752, 1-32.

Napoli, M.F. (2005) A new species allied to Hyla circumdata (Anura: Hylidae) from Serra da Mantiqueira, southeastern Brazil. Herpetologica, 61, 63-69.

Paolillo, O.A. \& Cerda, J. (1981) Nuevos hallazgos de Aparasphenodon venezolanus (Mertens) (Salientia, Hylidae) en el territorio federal Amazonas, Venezuela, con anotaciones sobre su biologia. Memoria de la Sociedad de Ciencias Naturales La Salle, 41, 77-95.

Pombal, J.P. (1993) New Species of Aparasphenodon (Anura: Hylidae) from Southeastern Brazil. Copeia, 1993, 1088-1091.

Rafinesque, C.S. (1815) Analyse de la Nature ou Tableau de l'Universe et des Corps Organisés. Jean Barravecchia, Palermo, $224 \mathrm{pp}$.

Rivero, J.A. (1961) Salientia of Venezuela. Bulletin of the Museum of Comparative Zoology, 126, 1-207.

Savage, J.M. \& Heyer, W.R. (1967) Variation and distribution in the tree-frog genus Phyllomedusa in Costa Rica, Central America. Beiträge zur Neotropischen Fauna, 5, 111-131.

Sazima, I. \& Cardoso, A.J. (1980) Notas sobre a distribuição de Corythomantis greeningi Boulenger, 1896 e Aparasphenodon brunoi Miranda-Ribeiro, 1920 (Amphibia, Hylidae). Iheringia, Série Zoologia, 55, 3-7.

Smith, H.M. (1939) Mexican herpetological novelties. Proceedings of the Biological Society of Washington, 52, 187-196.

Smith, S.A., Arif, S., Oca, A.N.M. \& Wiens, J.J. (2007) A phylogenetic hot spot for evolutionary novelty in Middle American treefrogs. Evolution, 61, 2075-2085.

Trueb, L. (1970) Evolutionary relationships of casque-headed treefrogs with co-ossified skulls. University of Kansas Publications, Museum of Natural History, 18, 547-716. 
Appendix 1. Additional species and specimens examined

Aparasphenodon brunoi. Brazil: State of Bahia: Porto Seguro, RPPN Estação Veracel, adult females (UFBA 3292 , 7662-7665), and adult male (UFBA 7666). Minas Gerais: Marliéria, Parque Estadual do Rio Doce, adult male (DZUFMG 186); Rio de Janeiro: Rio de Janeiro, Barra da Tijuca (MZUSP 123724-123767).

Aparasphenodon bokermanni. Brazil: São Paulo: Iguape, Estação Ecológica da Juréia-Itatins, adult female (ZUEC 6604, holotype); Cananéia, Ilha do Cardoso, adult male (ZUEC 11575). 